\title{
Characteristic of Bell's Palsy in Clinical Neurologic at Sanglah Hospital Denpasar Bali Indonesia
}

\section{Putu Ngurah Arya Darmawan ${ }^{1}$, Ni Made Dwita Pratiwi ${ }^{1}$ I Komang Arimbawa1}

${ }^{1}$ Department of Neurology, Faculty of Medicine, Udayana University, Denpasar, Bali, Indonesia

Corresponding Author: Ni Made Dwita Pratiwi

\begin{abstract}
Introduction/Aim: Bell's Palsy is a lower motor neuron facial weakness caused by idiopathic etiology with the absence of other neurologic diseases. The incidence of this syndrome is around 23 cases per 100,000 people each year. The clinical manifestations are sometimes being considered to be a stroke or tumor. This study was conducted to find characteristic of bell's palsy in clinical neurologic at Sanglah Hospital Denpasar, Bali Indonesia
\end{abstract}

Methods: This study is a descriptive study with a cross sectional design in polyclinic of Sanglah Hospital, Denpasar for the period 2016 to 2019. Sampling was carried out using a consecutive non-random sampling method.

Result: A total of 31 subjects in rainy season $51.6 \%$ having female $61.3 \%$ and male $38.7 \%$, with the range of age 46-55 years old. Most of the patients complaints the weakness of the right face $58.1 \%$, postauricular pain $64.5 \%$. Electroneuromyography examination with Seddon classification having results of Neuropraxia 67.7\%.

Conclusion: Characteristic of bell's palsy in clinical neurologic most of participant in woman with postauricular pain and neuropraxia

Keywords: Bell's Palsy, neuropraxia, postauricular pain, Seddon classification

\section{INTRODUCTION}

Bell's palsy is a unilateral weakness or paralysis of the lower motor neuron type in the face due to involvement of the peripheral facial nerves other than the central nervous system with unknown causes. This syndrome was first discovered in 1821 by a surgeon named Sir Charles
Bell, since then all asymmetric peripheral facial nerve paralysis of unknown cause is called Bell's palsy. The incidence of Bell's palsy in some countries is quite high, based on hospital statistics in the UK from the Health and Social Care Information Center from April 2011 to March 2015, hospital diagnoses of Bell's palsy increased by 13,463 cases. The incidence in India from 2014 to 2016 was 253 cases at RA Hospital \& Research Centre, Warisaliganj (Nawada). Global data show that each year the incidence is $11-40$ people per 100,000 diagnoses of Bell's palsy with a peak incidence at the age of 15 and 50 years, the average prevalence of male and female is the same.[1,2]

In Indonesia, the prevalence of cases of Bell's palsy is difficult to find. Because prevalence is not recorded in the Indonesian Health Profile and Basic Health Research by the Ministry of Health of the Republic of Indonesia, and research on the prevalence of Bell's palsy is not much. Data from 4 hospitals in Indonesia showed that the incidence of Bell's palsy was $19.5 \%$ of all neuropathy cases, and the most cases were at the age of 21-30 years. Diabetics have a $29 \%$ higher risk, compared to non-diabetics. Incidence of men and women with the same ratio. Third trimester pregnancy and 2 weeks postpartum the incidence of Bell's palsy is higher than non-pregnant women. The incidence of Bell's palsy in winter (November - March) is higher and the incidence in summer (May - September) is lower than the overall incidence.[3] 
The etiology of Bell's palsy is still unknown. There are five theories that are considered to be the cause of Bell's palsy, namely anatomy, viral infection, ischemia, inflammation and cold stimulation. The viral theory is more often discussed as the etiology of this disease.[2,4]

The mechanics of Bell's Palsy are still being discussed for years. In post mortem cases of Bell's palsy found the underlying pathophysiology is vascular, inflammation and edema with facial nerve ischemia. Many theories have been collected, one of which is that Bell's palsy is an acute demyelinating disease, which has similarities to the Guillain-Bare syndrome. Considered both to represent demyelinating inflammatory neuritis, Bell's palsy is considered a mononeuritic variant of the Guillain-Bare syndrome. In recent years reports, the possible cause of Bell's palsy is due to reactivation of herpes virus infection (HSV) in the geniculate ganglia and then migrates to the facial nerve. This herpes simplex virus mediates inflammation, causing nerve compression and clinical symptoms such as facial paralysis.[5,6]

Based on the location of the lesion, the clinical manifestations of Bell's palsy can be different. Lesions in the stylomastoid foramen, complete disruption can occur causing paralysis of all muscles of facial expression. When closing the eyelids, both eyes rotate upwards (Bell's phenomenon). The eyes can feel watery because the flow of the eye into the lacrimal sac assisted by the orbicularis oculi muscle is disturbed. Other complete manifestations are indicated by food being stored between the teeth and cheeks due to impaired facial movements and saliva coming out of the corners of the mouth. Lesions in the facial canal will exhibit all the symptoms such as lesions in the stylomastoid foramen plus loss of taste in the anterior two thirds of the tongue on the same side. If the lesion is on the nerve leading to the stapedius muscle, hyperacusis may occur. Lesions in the geniculate ganglion will cause lacrimation and reduced salivation and may involve the VIII nerve. $[5,7,8]$

The diagnosis can be made based on clinical symptoms of peripheral facial nerve palsy followed by examination to rule out other causes of peripheral facial nerve palsy.[1,9]

Some supporting examinations are important to determine the location of the lesion and the degree of facial nerve damage:

\section{Nerve excitability test}

This examination compares the contraction of the left \& right facial muscles after being given electrical stimulation. The difference in stimulation of more than $3.5 \mathrm{~mA}$ indicates a pathological condition and if more than $20 \mathrm{~mA}$ indicates irreversible facial nerve damage.

\section{2. nerve conduction test}

Examination to determine the degree of denervation by measuring the speed of electrical conduction in the right and left facial nerves

\section{Electroneurography}

An examination that shows the functioning or not of the facial muscles with significant electroneurographic findings. The significant electroneurography results referred to in this case are the R1 latency not exceeding $13 \mathrm{~ms}$, the R2 latency not exceeding $40 \mathrm{~ms}$ ipsilaterally and not exceeding $41 \mathrm{~ms}$ contralateral to the stimulus, the difference in latency between the two sides is not more than $1.5 \mathrm{~ms}$ for $\mathrm{R} 1$ and not more than $8 \mathrm{~ms}$ for R2.

4. Test the function of the taste buds of the front $2 / 3$ of the tongue

Giroy and Mayer (1979) suggested examining taste buds by means of sweetness (sugar), sour taste and bitter taste (quinine pills). Electrogustometry compares the reaction between the healthy and diseased sides with electrical stimulation of $2 / 3$ of the tongue to the taste of bitter or metallic soy sauce. Taste disturbances in Bell's 
palsy indicate the location of the facial nerve lesion at the level of the chorda tympani or proximal.

\section{Schirmer's test}

This examination uses a special filter paper that is placed behind the left and right lower eyelids. Assessment in the form of tear seepage on filter paper; reduced or dry tears indicate facial nerve lesions at the level of the geniculate ganglion. 2,11,12

At Sanglah Hospital in the neurology department, Bell's palsy is the most common neuropathy. However, there has been no research on the characteristics of Bell's palsy sufferers at Sanglah Hospital, regarding epidemiology, clinical symptoms or from the results of supporting examinations, especially electroneurography in the form of CMAP $m$ assessment. orbicularis oculi right and left. So, this study was conducted to determine the characteristics of patients suffering from Bell's palsy in the neurology department of Sanglah Hospital.

\section{METHOD AND PROCEDURES}

This research is a descriptive study using a cross-sectional study design, the research data was taken over a period of 3 years from 2017 to 2019. The research was conducted at the neurology department of the Sanglah Central General Hospital, Denpasar, Bali. The research sample was taken using consecutive non-random sampling method. The study population was all patients who went to the neurology department of Sanglah Hospital. The research sample was patients who went to the neurology department with complaints of unilateral facial weakness, reduced tears, hyperacusis and reduced taste sensation in the front $2 / 3$ of the tongue.

Patients suspected of Bell's palsy from history and supporting examination were then subjected to electroneurography examination. The results of the examination recorded were R1 latency, ipsilateral and contralateral R2 latency on recordings in the right and left orbicularis oculi muscles. How to manage data using SPSS version 20 statistics program.

\section{RESULT}

Research on the characteristics of Bell's palsy patients at Sanglah Hospital Denpasar has been carried out from 2016 to 2019 in the neurology department and medical records at Sanglah Hospital Denpasar. This research was conducted by taking secondary data from medical records.

Total of registered Bell's palsy patients from 2016 to 2019 at Sanglah Hospital Denpasar is 45 people. Of 45 patients, only 31 medical records were available and used as a sample population for inclusion in the study. Data taken from medical records were gender, onset, age, paralyzed side of the face, hearing loss, painful ear side, electroneurophysiology and accompanying symptoms at table 1 .

\begin{tabular}{|c|c|c|c|}
\hline Variable & & Amount & $\begin{array}{l}\text { Percent } \\
\text { (\%) }\end{array}$ \\
\hline \multirow[t]{2}{*}{ Gender } & Female & 19 & 61,3 \\
\hline & Male & 12 & 38,7 \\
\hline \multirow[t]{3}{*}{ Season } & Rain (10-3) & 16 & 51,6 \\
\hline & $\begin{array}{l}\text { Transition } \\
(4,5,9)\end{array}$ & 8 & 25,8 \\
\hline & Summer (6-8) & 7 & 22,6 \\
\hline \multirow[t]{7}{*}{ Age } & $\begin{array}{l}\text { Early teens } \\
{[12-16]}\end{array}$ & 3 & 9,7 \\
\hline & $\begin{array}{l}\text { Late teens } \\
{[17-25]}\end{array}$ & 5 & 16,1 \\
\hline & $\begin{array}{l}\text { Early adult } \\
\text { [26-35] }\end{array}$ & 3 & 9,7 \\
\hline & $\begin{array}{l}\text { Late adult } \\
\text { [36-45] }\end{array}$ & 3 & 9,7 \\
\hline & $\begin{array}{l}\text { Early elderly } \\
{[46-55]}\end{array}$ & 11 & 35,5 \\
\hline & $\begin{array}{l}\text { Late elderly } \\
\text { [56-65] }\end{array}$ & 4 & 12,9 \\
\hline & old age [>65] & 2 & 6,5 \\
\hline \multicolumn{4}{|l|}{ Clinical neurologic } \\
\hline \multirow[t]{2}{*}{ Face lesion side } & Right & 18 & 58,1 \\
\hline & Left & 13 & 41,9 \\
\hline \multirow[t]{2}{*}{ Postauricular pain } & Pain & 11 & 35,5 \\
\hline & No Pain & 20 & 64,5 \\
\hline \multirow[t]{3}{*}{ Haring Loss } & Hyperacusis & 7 & 22,6 \\
\hline & Hearing loss & 2 & 6,5 \\
\hline & Normal & 22 & 71,0 \\
\hline \multicolumn{4}{|c|}{ Electroneuromyography examination } \\
\hline \multirow{3}{*}{$\begin{array}{l}\text { CMAP Orbicularis } \\
\text { Oculi }\end{array}$} & Neuropraxia & 21 & 67,7 \\
\hline & Aksonometsis & 3 & 9,6 \\
\hline & Normal & 7 & 22,8 \\
\hline
\end{tabular}

Source: Medical Records Sanglah Hospital Denpasar

\section{DISCUSSION}

The results showed that the proportion of Bell's palsy sufferers was 
more in women as much as $61.3 \%$, this is in accordance with research and theory in Indonesia which says Bell's palsy regarding female is higher than male. Based on research conducted by Finsterer in 2008 and Greco in 2012 stated that there was no difference in prevalence by gender.[8,9]

From this study, it was found that the most subjects suffering from Bell's palsy were in the rainy season as many as 16 patients (51.6\%) and the lowest summer was 7 patients (22.6\%). Research conducted by Campbell in 2002, stated that the incidence of sufferers of Bell's palsy in winter (November-March) was higher, while the incidence in summer was low. Exposure to cold air can trigger activation of herpes simplex virus type 1 (HSV-1) and prolonged exposure to cold outside can cause vasomotor changes in the facial area, ranging from edematous neuritis to ischemic reflexes.[8]

From this study, it was found that the most Bell's palsy subjects were in the 46-55 year old group, namely 11 people (35.5\%) and the lowest was in the $0-5$ year old and 5-11 year age group, namely 0 . From the research made by Finsterer in 2008 and Annsilva in 2010 show that, the peak incidence occurs between the second and fourth decades (15-45 years). Bell's palsy is rare in children $<2$ years and the incidence increases with age after 60 years.[9]

In this study, the most subjects on the right side of the face were 18 patients (58.1\%). On the left and right side or bilateral face not found in the medical record. Based on research conducted in 2008 by Finsterer and Annsilva in 2010 stated, there was no difference on the right or left side of the face, more often on one side (unilateral), rarely bilateral and can recur.[4,9]

In this study, the most common postauricular pain found was that there were no complaints of postauricular pain, as many as 20 patients (64.5\%). Based on a study conducted in 2002 by Peitersen, it was stated that almost $50 \%$ of complaints of pain were additional symptoms that were often found in Bell's palsy patients. Pain may occur with facial paralysis or occur before the onset of paralysis.[4]

In this study, obtained based on hearing loss, the most in the normal category were 22 patients (71\%). At least found in the category of hyperacusis there are 2 patients $(6.5 \%)$. Based on research conducted by Finsterer in 2008 and Ronthal in 2012 stated that the clinical picture varies, depending on the location of the lesion of the facial nerve along its way to the muscle. Clinical features that are often found are lowered eyebrows, forehead is not wrinkled, unable to close the eyes, the eyeballs roll up (Bell's phenomenon), the nasolabial angle is not visible and the mouth is pulled to the healthy side. Other symptoms are reduced tearing, hyperacusis and reduced taste sensation in the front two thirds of the tongue[6,9]

In this study, based on the results of electroneurography according to the Seddon classification, the most found in the category of neuropraxia were 21 patients (67.7\%). The least found in the axonotmesis category were 3 patients (9.6\%). This is in accordance with the criteria for peripheral nerve injury according to Seddon, namely if a conduction block is found in the form of prolonged latency on the side of the lesion, the normal value of $\mathrm{R} 1$ is about $10 \mathrm{~ms}$ and $\mathrm{R} 2$ is about $30 \mathrm{~ms}$. The advantage of electroneurography is to predict the prognosis in the early stages of facial paralysis, because conduction block and axonal degeneration coexist in Bell's plasy. In addition, several studies have attempted to use electroneurography to define surgical interventions such as facial nerve decompression. The prognosis in the neuropraxia category is good, in the axonotmesis category the prognosis depends on the axon regeneration process and sometimes requires surgery, while the neurotmesis category is the worst prognosis and almost always requires surgery.[10-12] 


\section{CONCLUSION}

This study used 31 samples. Bell's palsy patients are mostly found on the right side of the face, and female are more at risk than male. The distribution based on complaints of postauricular pain was found in the category of no complaints of postauricular pain and the most in the age group of 46-55 years. The most complaints were found in the rainy season and the distribution based on hearing loss was found in the normal category. From the electroneurography examination according to the Seddon classification, it was found that $67.7 \%$ had neuropraxia with a good prognosis.

\section{Informed Consent and Patient Details}

The authors declare that this research does not contain any personal information that could lead to the identification of the patient(s) and/or volunteers.

\section{Funding}

This work did not receive any grant from funding agencies in the public, commercial, or not-for-profit sectors.

\section{Ethics Committee Approval}

This study has obtained ethical clearance issued by the Research Ethic Commission of Faculty of Medicine, Udayana University, Sanglah General Hospital, Denpasar.

\section{Conflict of Interest}

There are no conflicts of interest to declare by any of the authors of this study.

\section{REFERENCES}

1. Moch B. Bell's Palsy (BP). Saintika Med. 2017;7(2):20-5.

2. Cooper L, Branagan-harris M, Tuson R, Nduka C. Lyme disease and Bell 's palsy: Br J Gen Pract. 2017;(May):e329.

3. Yuliani NF. Penatalaksanaan fisioterapi pada kondisi Bell's palsy dextra di RSAL Dr. Ramelan Surabaya. 2016;1-12.
4. Campbell KE, Brundage JF. Effects of climate, latitude, and season on the incidence of Bell's palsy in the US Armed Forces, October 1997 to September 1999. Am J Epidemiol. 2002;156(1):32-9.

5. Zandian A, Osiro S, Hudson R, Ali IM, Matusz P, Tubbs SR, et al. The neurologist's dilemma: A comprehensive clinical review of Bell's palsy, with emphasis on current management trends. Med Sci Monit. 2014;20:83-90.

6. Greco A, Gallo A, Fusconi M, Marinelli C, Macri GF, de Vincentiis M. Bell's palsy and autoimmunity. Autoimmun Rev. 2012;12(2):323-8. DOI: 10.1016/j.autrev.2012.05.008

7. Schwartz R, Murray C, Deckard NA. Clinical Practice Guideline Summary: Bell 's Palsy. 2013;(November):34-5.

8. Kubik M, Robles L, Kung D. Familial Bell's Palsy: A Case Report and Literature Review. Case Rep Neurol Med. 2012;2012:1-3.

9. Finsterer J. Management of peripheral facial nerve palsy. Eur Arch Oto-RhinoLaryngology. 2008;265(7):743-52.

10. Cui H, Zhong W, Zhu M, Jiang N, Huang $\mathrm{X}$, Lan $\mathrm{K}$, et al. Facial Electromyography Mapping in Healthy and Bell's Palsy Subjects: A High-Density Surface EMG Study. Proc Annu Int Conf IEEE Eng Med Biol Soc EMBS. 2020;2020-July:3662-5.

11. Li P, Qiu T, Qin C. Efficacy of acupuncture for Bell's palsy: A systematic review and meta-analysis of randomized controlled trials. PLoS One. 2015;10(5):1-14.

12. Hwang J-M, Kim J-Y, Kim H-N, Park K-J, Jo M-G, Jang J-Y, et al. Comparative Review of the Correlation Between Electroneurography, Electromyography, Hematology Tests, or the Heart Rate Variability Test, with an Improvement in the Severity of Bell's Palsy Symptoms. J Acupunct Res. 2021;38(3):192-9.

How to cite this article: Putu Ngurah Arya Darmawan, Ni Made Dwita Pratiwi, I Komang Arimbawa. Characteristic of bell's palsy in clinical neurologic at Sanglah Hospital Denpasar Bali Indonesia. International Journal of Research and Review. 2021; 8(12): 318-322. DOI: https://doi.org/10.52403/ijrr.20211239 